Recepción: 15 / 04 / 2017

Aceptación: 01 / 05 / 2017

Ciencias Pedagógicas

Publicación: 15 / 05 / 2017

Articulo Científico

\title{
Factores que afectan la intención empresarial de los estudiantes universitarios mayores
}

\author{
Factors affecting entrepreneurial intention of \\ senior University Students
}

Fatores que afetam a intenção empresarial dos

\section{Alunos Universitários}

\author{
Wellington A. Alvarez-Baque \\ walvarezb@unemi.edu.ec \\ José L. Tenório-Almache ${ }^{\mathrm{II}}$ \\ jtenorioa@unemi.edu.ec \\ Katuska I. Cepeda-Ávila III \\ katuska.cepedaa@ug.edu.ec \\ Luis G. Cañizares-Vásquez ${ }^{\text {IV }}$ \\ luis.canizaresv@ug.edu.ec
}

Correspondencia: jtenorioa@unemi.edu.ec

Master of Science in International Management With Marketing; Bachelor of Science in Markenting; Universidad Estatal de Milagro, Ecuador.

II. Magister en Administración de Pequeñas y Medianas Empresas; Ingeniero Comercial mención Administración Financiera; Universidad Estatal de Milagro, Ecuador.

III. Magister en Administración Publica mención Desarrollo Institucional; Diploma Superior en Sistemas de Educación Superior Modular Basados en Créditos Acumulables y Transferibles; Diseñador de Interiores; Universidad de Guayaquil, Ecuador.

Iv. Magister en Sistemas de Producción y Productividad; Ingeniero Industrial, Universidad de Guayaquil, Ecuador. 


\section{Resumen}

El presente trabajo de investigación tiene como objetivo medir la intención y percepción que tienen los estudiantes universitarios del último año hacia el emprendimiento de un negocio. Para esto, se ha realizado un banco de preguntas que se aplicó mediante un cuestionario a 206 estudiantes de la Facultad de Negocios de las cinco carreras que se ofertan; midiéndose seis diferentes criterios que se consideró de influencia en la creación de un negocio. Los criterios medidos fueron: Intención en la creación de empresa, tiempo de creación, Influencia de la formación Universitaria, factores externos que influyen en la decisión, factores que motivan y factores que desmotivan. Los resultados alcanzados nos permiten observar que la mayoría de los estudiantes tienen el deseo y la motivación de emprender. Se pudo observar que de manera positiva influye en la intención de crear su negocio factores como la formación universitaria, familia, amigos, deseo por alcanzar su independencia económica, ganar dinero, lograr su autorrealización y superación personal. Por el contrario las barreras que desmotivan al estudiante serían: el escaso capital para iniciar un negocio, falta de apoyo de entidades públicas o privadas y la carga académica mientras cursan sus estudios. Los resultados son de importancia debido a que estos le permiten a las Universidades entender las diferentes actividades requeridas por los estudiantes antes de que terminen sus carreras.

Palabras clave: Emprendimiento; estudiantes universitarios; intenciones empresariales; motivaciones; negocios. 


\begin{abstract}
The aim of this study was to investigate the senior university student's perceptions and intentions towards entrepreneurship of a business. To achieve the research objectives, a questionnaire was used to collect the data, where 206 students of the Business Faculty participated. The study included all the students of the last two semesters from the different five careers options that the Faculty offers where six different factors were considered to determine their influence in the start-up of a business. The different criteria measured were: business start-up intention, length to begin, influence of University education, external factors that could influence in their decision and aspects that motivate and demotivate. The analysis of the results shows that most of the students have a desire and feel motivated to become an entrepreneur. The survey revealed that some factors - i.e university education, family, desire to become financially independent, earn money and to get personal development and self-fulfillment play an important role when considering starting up a business. On the other way, the barriers that could demotivate students of deciding whether to start a business or not could be: lack of capital to begin, insufficient support from the public and private sector and the excessive academic responsibilities. The results are of importance because they allow Universities to understand the different activities needed by students before they finish their careers.
\end{abstract}

Key words: Entrepreneurship; university students; entrepreneurial intentions; motivations; business. 


\section{Resumo}

O objetivo deste estudo foi investigar as percepções e intenções do estudante universitário superior em relação ao empreendedorismo de uma empresa. Para a realização dos objetivos da pesquisa, foi utilizado um questionário para coleta de dados, onde participaram 206 alunos da Faculdade de Administração. $\mathrm{O}$ estudo incluiu todos os alunos dos últimos dois semestres das diferentes cinco carreiras opções que a Faculdade oferece onde seis fatores diferentes foram considerados para determinar a sua influência no início de uma empresa. Os diferentes critérios avaliados foram: intenção de início de negócio, duração do início, influência da formação universitária, fatores externos que podem influenciar na decisão e aspectos que motivam e desmotivam. A análise dos resultados mostra que a maioria dos alunos tem um desejo e se sente motivado para se tornar um empreendedor. A pesquisa revelou que alguns fatores - isto é, educação universitária, família, desejo de se tornar financeiramente independente, ganhar dinheiro e obter desenvolvimento pessoal e autorealização desempenham um papel importante quando se considera iniciar um negócio. Por outro lado, as barreiras que poderiam desmotivar os estudantes para decidir se iniciar ou não um negócio poderiam ser: falta de capital para começar, apoio insuficiente do setor público e privado e as excessivas responsabilidades acadêmicas. Os resultados são importantes porque permitem que as universidades compreendam as diferentes atividades que os alunos precisam antes de terminarem suas carreiras.

Palavras chave: Empreendedorismo; estudantes universitários; intenções empresariais; motivações; o negócio. 


\section{Introducción.}

In today's competitive job environment, finding a job can be challenging, especially when tending to be employed in big firms. Big firms employ fewer applicants and long-term employment is becoming more or less like a dream and higher education is no longer an ace for being employed. This is why the term Entrepreneurship has become an everyday buzzword. Policymakers, economist and academics are talking about it. They highlight about the importance that entrepreneurship represent to countries, societies and individual development (Keat, Selvarajah, \& Meyer, 2011). That is why there is increase awareness from public authorities to promote entrepreneurship especially among Universities which are seen as potential sources of future entrepreneurs (Smith \& Beasley, 2011).

There exist other studies that indicate a connection between education and entrepreneurship (Van Gelderen et al., 2009). One of the first steps to develop an entrepreneurial career is to form an intention (Iakovleva, Kolvereid, \& Stephan, 2011). Among the theories which can predict entrepreneurial intentions are those by Azjen (1991) known as the theory of planed behaviour (TPB), the theory of entrepreneurial event by Shapero and Sokol's (1982), the model of implementing entrepreneurial ideas by Bird (1988), and the maximization of expected utility model by Douglas and Shepherd (2002) (Marques, Ferreira, Gomes, \& Ricardo, 2014). Among these theories, the TPB has been shown to predict entrepreneurial intentions most consistently. Unlike other models, the TPB is one of the most rational and applicable theoretical framework because it allows us to comprehend and forecast entrepreneurial intention by taking into account social and personal factors (Iakovleva et al., 2011). There exist three especial aspects hypothesized by the TPB which drive behavioural intentions. They are attitudes towards the behavior, subjective norms and perceived behavioural control (Figure 1). 
Entrepreneurial intent remains an important part of start-up process and is worthy of attention in its own right. This is why a model is proposed in this study (figure 1) which joins the TPB with the motivational and demotivational factors taken in consideration in this research.

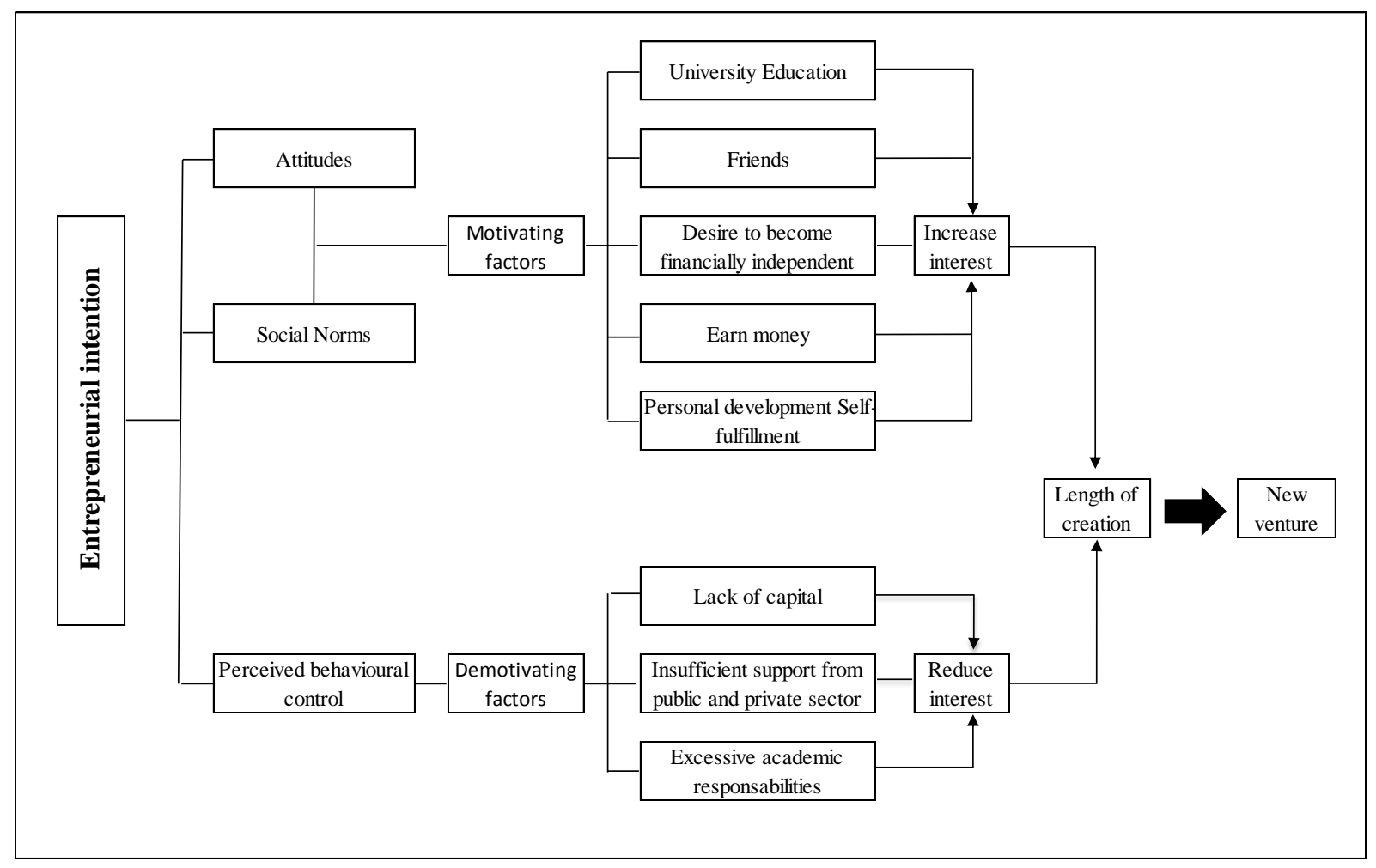

Figure 1. Facors affecting entrepreneurial intention - Adapted from Ajzen TPB $(1980,1991)$

Hence it is the objective of this work to make a contribution to the current literature by discussing the variables or factors that can influence students' inclination towards entrepreneurship they will be studied in detail.

Azjen defined attitude as the degree to which a person has positive or negative attitude towards a behaviour (Solesvik, Westhead, Kolvereid, \& Matlay, 2012). According to the TPB, individuals who are more flexible about attitudes towards the behaviour would be more likely to try and take the action to become 
an entrepreneur. They include not only affective (I like it, it is attractive) but also evaluative (it has advantages) considerations. Social Norms refer to the perceived social pressure to perform or avoid behaviour. It consists of two components: normative beliefs and the motivational to comply with these beliefs (Iakovleva et al., 2011). According to Ajzen (1991) normative beliefs are concerned with the possibility that other persons could think about a specific behavior, and motivation to comply is an assessment of how important it is to have approval of important others (i.e. family members, close friends and other influential people such as teachers, successful entrepreneurs, enterprise advisors, etc.) which are believed to shape the formation of entrepreneurial intentions (Ajzen, 2002).

The first two factors proposed by Azjen in its TPB, which suggest that attitudes and subjective norms determine intentions are broaden in this study considering the different variables that can play a role in taking the intent to the actual new venture creation (figure 1). These are explains below:

- University education: Schools and universities are of importance for shaping students while they are studying because educational institutions are ideally considered the place to start promoting an entrepreneurial culture which help them in the future to think as entrepreneurs (Keat et al., 2011)

- Family: The intentions to become an entrepreneur are stronger as well as the final decision to create a business more probable when there exist social support considering of special importance the role of the family whether it has a business or not.(Díaz, Hernández Mogollón, \& Raposo, 2007)

- Friends: Authors like Nanda and Sorensen recognize the importance of peers because people can be induced to take the decision to become entrepreneurs. (Keat et al., 2011) They suggest that there exist a positive effect transferred by those who have had previous experience in self-employment which have a direct impact on individuals when considering starting a new business or not.

- Desire to become financially independent: Many students would like not to depend on others to support their living expenses and this desire drives them into looking the ways to find its own resources and become independent. 
Wellington A. Alvarez-Baque; José L. Tenório-Almache; Katuska I. Cepeda-Ávila; Luis G. Cañizares-Vásquez

- Earn money: This factor becomes of importance because students would like to increase their standard of living in the short-run and to gain a different social status. People would become entrepreneurs if the expected rewards surpass the wages of employment. (Segal, Borgia, \& Schoenfeld, 2005)

- Personal development / Self-fulfillment: individuals will feel they are successful when they can realize that have reached their goals (Montoya, n.d.).

It is unbelievable to think that in order for a person to have the motivation to become an entrepreneur, all the above factors have to be reached. On the contrary, the intentions will depend on other factors that could reduce its level of motivation. This is where the third component of the TPB takes place

Known as Perceived behavioural control. More exactly, this refers to the perceived ease or difficulty that a person can find in performing or behaving someway (Iakovleva et al., 2011). In the model proposed (figure 1), three variables like lack of capital, insufficient support from the public and private sector and the excessive academic responsibilities might become a factor of demotivation which reduces the interest of becoming an entrepreneur.

As it has been explained above, there are many factors that could lead university students to have the intention to create a new venture. Therefore the objective of this study is to carry out an analysis of the entrepreneurial intention that students may have at the University in Milagro, Ecuador. In the study, some factors that might have an impact on students' decision were tested on a sample of 206 University students from a public University considering just ones who are in their last year and belong to the Business Faculty. What is more, this study will attempt to make a contribution to the different theories analyzing how certain factors can affect students in their intentions to start a business. It is expected that the results may have some relevant considerations by policy makers and educators.

\section{Methodology.}

The methodology used in this research is based on a descriptive, cross-sectional study where data was collected, measured and evaluated in order to get relevant information about general aspects of entrepreneurs, 
the different factors that might influence in a positive or negative way at the moment of deciding whether to start a business or not. The research techniques used was the bibliographical revision and surveys which were administered to a sample of 206 students from the last two semesters considering the five careers options that the Business Faculty offers. To collect data a survey was carried out based on questionnaire of 18 questions which were grouped into six criteria: Criteria 1, Intention to start a business; Criteria 2, Length to start-up; Criteria 3, influence of university education; Criteria 4, external factors; Criteria 5, factors that motivate students to start a new venture; Criteria 6, demotivation factors that stops students to launch their own business.

The scales used in the questionnaire implemented are based taking as a reference the contributions of Tarapuez et al., (2015) in their study "Elements for building an instrument to measure entrepreneurship in last term bachelor students".

\section{Results.}

In order to study the different criteria that may influence in a positive or negative way the student's intention toward starting a business or not, different tables were created which grouped all the criteria into four factors: Individual, external, motivational and demotivational.

The first factor to analyse has to do with the individual about its intentionality to start a business and how long it could take before this happen (Table 1). It was found that a great majority of student have the desire to start a business representing the $87 \%$. Another important factor to consider are those students who already own a business which is about $7 \%$ and the $6 \%$ of them who have no intention to launch or start entrepreneurial activities. Perhaps this last portion of students feels more secure just to find a job and earn quick money.

Also of importance is the length to start-up because there was no significance difference between students who want to start a new business as soon as they finish their studies and those who have no idea when to start. 
Wellington A. Alvarez-Baque; José L. Tenório-Almache; Katuska I. Cepeda-Ávila; Luis G. Cañizares-Vásquez

Table 1. Individual factors that may influence entrepreneurial intention of Senior students

\begin{tabular}{|c|c|c|c|}
\hline Factor & Criteria & Question & Outcome \\
\hline \multirow{5}{*}{ Individual } & Intention to start a business & $*$ & $87 \%$ desire to launch their own business \\
\hline & & & $7 \%$ already have a business \\
\hline & & & $6 \%$ have no intentions \\
\hline & Length to start-up & $* *$ & $34 \%$ don't know when \\
\hline & & & $34 \%$ As soon as I finish my studies \\
\hline
\end{tabular}

* Do you have the intention to start your own business?

** When do you estimate that you can start your own business?

Having the intention is very important to take the risk of starting a new business, but there might be other factors that help students to be involved in business somehow. This can be called external factors shown in (Table 2) 
Factores que afectan la intención empresarial de los estudiantes universitarios mayores

Table 2. External factors that may influence entrepreneurial intention of Senior students

\begin{tabular}{|c|c|c|c|}
\hline Factor & Criteria & Question & Outcome \\
\hline \multirow{5}{*}{ External } & Influence of studying at UNEMI & $*$ & $\begin{array}{l}77 \% \text { agree that the University has } \\
\text { provided them with the skills and knowledge }\end{array}$ \\
\hline & Family members & $* *$ & $56 \%$ have relatives with businesses \\
\hline & & & $41 \%$ don't have relatives with busineses \\
\hline & Work experience & $* * *$ & $57 \%$ have been employed \\
\hline & & & $42 \%$ has never worked \\
\hline
\end{tabular}

* Do you consider that the University has provided you with all the necessary skills and knowledge to launch your own business?

** Any of your family members (parents, brother or grandparents) have a business?

*** Do you have any work experience or have you been employed by any company?

It can be observed in the above table that the majority of students $77 \%$ agree that University has provided them with the enough skills and knowledge to start a business which validate that Universities are playing its role of forming entrepreneurs.

Table 2 also shows that there is not a great difference between those students who have relatives with businesses and those who don't. Still, $41 \%$ is a great number to consider because it might explain why many students have the resistant toward entrepreneurship due to they have nobody in their family to follow as an example. Another important issue to take in consideration is about its work experience because even though the portion of students with work experience is higher by $15 \%$, it is important to remark that $42 \%$ is also a big number that need to be paid attention and find somehow the way these students start practicing what they learn in their classroom.

Become an entrepreneur can take a long way, so feeling motivated play an important role for not giving up in the short-run. The next table (Table 3) analyses those factors that keep student going in their dreams to become successful entrepreneurs. 
Wellington A. Alvarez-Baque; José L. Tenório-Almache; Katuska I. Cepeda-Ávila; Luis G. Cañizares-Vásquez

Table 3. Motivational factors that may influence entrepreneurial intention of Senior students

\begin{tabular}{llcc}
\hline Factor & \multicolumn{1}{c}{ Criteria } & Question & Outcome \\
\hline & $\begin{array}{l}\text { Being your own boss, manage } \\
\text { my time, being independent }\end{array}$ & $*$ & $95 \%$ agree with this statement \\
Motivational & $\begin{array}{l}\text { Personal development } \\
\text { Self-fulfillment }\end{array}$ & $* *$ & $94 \%$ consider of importance \\
& Earn money & $* * *$ & $97 \%$ expect this \\
\hline
\end{tabular}

* The intention that motivates you for a new venture creation would be to become your own boss, manage your time or being independent?

** The intention that motivates you for a new venture creation would be for personal development and self-fulfillment?

*** The intention that motivates you for a new venture creation would be to earn money?

The majority of the students, $95 \%$ see as positives factors the possibility of being its own boss, manage their own time and being independent. All these three variables should be useful to understand that being entrepreneurs could bring great benefits in the long-run. The $94 \%$ of students confirm what is known as the Maslow theory (1943) which suggests that individuals, in this case students; will feel motivated to reach the top of the pyramid where they reach their self-fulfillment.

Earning money is the top factor for students in their intention to start a business representing the 97\%. This might be the main cause why many entrepreneurship projects fail because they expect money in the short-run, however there exist evidence from successful entrepreneurs who suggest that it is a process and that might take several years before money can be actually earned, in many cases, they need to lose money or reinvest what they earn gradually.

Finally and according to the model proposed in the literature, three aspects that could demotivate students to start a business are: Lack of capital, insufficient support from public and private sector and excessive university responsibilities. All these are presented in table 4. 
Table 4. Demotivational factors that may influence entrepreneurial intention of Senior students

\begin{tabular}{llll}
\hline Factor & \multicolumn{1}{c}{ Criteria } & Question & \multicolumn{1}{c}{ Outcome } \\
\hline & Lack of capital & $*$ & $87 \%$ consider of great importance \\
Demotivational & $\begin{array}{l}\text { Insufficent support from public } \\
\text { and private sector }\end{array}$ & $* *$ & $61 \%$ agree with this statement \\
& $\begin{array}{l}\text { Excessive university } \\
\text { responsabilities }\end{array}$ & $* * *$ & $91 \%$ stated this \\
\hline
\end{tabular}

\footnotetext{
* The intention that demotivates you for a new venture creation would be the lack of capital?

** The intention that motivates you for a new venture creation would be insufficient support from public and private sector?

*** The intention that motivates you for a new venture creation would be the excessive university responsabilities?
}

The money is always an engine to do many things. In this study, $87 \%$ of the students considered of importance. However this could be overcome if they understood the mechanism to get access to loans. There also exists the perception among students that there is insufficient support either from public or private sectors to support them with their project ideas.

Another thing to consider is the time that students spend during their whole career which may be an advantage for them to launch a business; however the $91 \%$ of them agree that they have excessive university responsibilities which not let them to work in other activities.

\section{Conclusions.}

The results obtained in this research highlighted the entrepreneurial intention of universities students of the last two semesters of the Business Faculty. It was found that there exist a great percentage of students who desire to launch their own business; however some of them have not decided yet when to start even though they agree that the University is providing them with the knowledge and skills. It needs to be considered in future research the different aspects that stop this proportion of students to start their business. 
Wellington A. Alvarez-Baque; José L. Tenório-Almache; Katuska I. Cepeda-Ávila; Luis G. Cañizares-Vásquez

I would also be a good contribution if Universities could connect those students who have relatives with businesses or work experience with those who still need to put theory into practice. That would be of great impact since the study shows that the majority of the students feel motivated to start a new venture for reasons like being their own boss, personal development and self-fulfillment.

Additionally, the faculty has to start different campaigns to promote entrepreneurship among students starting form the first years to allow them to learn step by step and getting an entrepreneurial viewpoint in relation with other students who can exchange experiences and share knowledge.

It is also of importance to make different workshops which explain students all the mechanism that exists to get financial support from the public and private sectors. This could help them for not feeling demotivated at the moment of starting a business and not having the enough capital.

Furthermore, it could be great if the students could do more visits or internships in different businesses, especially little entrepreneurs where they can learn about the dreams and the struggle to keep going to get successful. Also, it would be of great impact to include during their whole university life more courses which train them not only in the abilities and skills to start a business, but once the business is running how to make it grow with different marketing strategies.

Finally, this research has showed that there exist a great entrepreneurial capacity among university students who seem eager to take the risk and start their own businesses and that is why Universities need to keep playing an important role in forming this kind of students who are vital to increase productivity and become more competitive which result in creating more jobs and well-being for their stakeholders.

\section{References.}

Ajzen, I. (1991). The Theory of Planned Behaviour, Organizational Behaviour and Human Decision Processes, 50 (2), 179-211.

Ajzen, I. (2002). Constructing a TpB questionnaire: conceptual and methodological considerations. Retrieved from: http://www.unibielefeld.de/ikg/zick/ajzen\%20construction\%20a\%20tpb\%20questionnaire.pdf 
Bird, B. (1988). Implementing entrepreneurial ideas: the case for intentions. Academy of Management Review, 13 (3), 442-53.

Díaz, J. C., Hernández Mogollón, R., \& Raposo, M. L. B. (2007). Estudiantes universitarios y creación de empresas. Un análisis comparativo entre España y Portugal. Conocimiento, Innovación Y Emprendedores: $\quad$ Camino Al Futuro, 97. Retrieved from http://dialnet.unirioja.es/servlet/articulo?codigo=2234363\&info=resumen\&idioma=SPA

Douglas, E.J. \& Shepherd, D.A. (2002). Self-employment as a career choice: attitudes, entrepreneurial intentions, and utility maximization. Entrepreneurship Theory and Practice, 18 (3), 5-10.

Iakovleva, T., Kolvereid, L., \& Stephan, U. (2011). Entrepreneurial intentions in developing and developed countries. Education + Training, 53(5), 353-370. http://doi.org/10.1108/00400911111147686

Keat, O. Y., Selvarajah, C., \& Meyer, D. (2011). Inclination towards entrepreneurship among university students : An empirical study of Malaysian university students. International Journal of Business and Social Science, 2(July 2015), 206-220.

Marques, C. S., Ferreira, J. J., Gomes, D. N., \& Ricardo, G. R. (2014). Entrepreneurship education. Theory an Dpractice in Entrepreneurship Education, (March), 1-14. http://doi.org/http://dx.doi.org/10.1108/17506200710779521

Montoya, G. G. (n.d.). Educación emprendedora en la universidad: Educando para el futuro Educating for the future, 2(1), 49-68.

Segal, G., Borgia, D., \& Schoenfeld, J. (2005). The motivation to become an entrepreneur. International Journal of Entrepreneurial Behavior \& Research, 11(1), 42-57. http://doi.org/10.1108/13552550510580834

Shapero, A. \& Sokol, L. (1982). The social dimension of entrepreneurship. In Kent, C.A., Sexton, D.L. \& Vesper, K.H. (Eds), Encyclopedia of Entrepreneurship: 72-90. New Jersey, United States: PrenticeHall, Inc.

Smith, K., \& Beasley, M. (2011). Graduate entrepreneurs: intentions, barriers and solutions. Education + Training, 53(8/9), 722-740. http://doi.org/10.1108/00400911111185044

Solesvik, M. Z., Westhead, P., Kolvereid, L., \& Matlay, H. (2012). Student intentions to become selfemployed: the Ukrainian context. Journal of Small Business and Enterprise Development, 19(3), 441-460. http://doi.org/10.1108/14626001211250153

Tarapuez, E., García, M., Castellano, N. (2015). Elements for building an instrument to measure. Tendencias. 16 (2), 209-227.

Van Gelderen, M., Brand, M., Van Praag, M., Bodewes, W., Poutsma, E., Van Gils, A. Selcuk, S. S. (2009). Which factors affect entrepreneurial intention of university students? Journal of European Industrial Training Journal of Small Business and Enterprise Development Is Career Development International Iss International Journal of Entrepreneurial Behaviour \&amp; Research, 33(1), 142-159. http://doi.org/10.1108/03090590910939049 